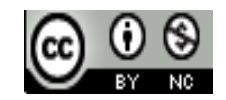

Jurnal Pendidikan Matematika Indonesia is licensed under A Creative Commons Attribution-Non Commercial 4.0 International License.

\title{
PROBLEM SOLVING ABILITY IN PROBABILITY THEORY THROUGH PROBLEM SOLVING BASED LEARNING
}

\author{
Jamilah $^{1)}$ \\ 1) IKIP PGRI Pontianak, Pontianak, Indonesia \\ E-mail: jemiaisyah@yahoo.com
}

\begin{abstract}
The aims of this study are to determine level of problem solving ability after being given problem solving based learning and to determine the effect of problem solving based learning to problem solving ability in probability theory. The method used is quasi experimental, with pre-experimental design and one shot case study design. The population are the students of fifth semester in IKIP PGRI Pontianak and it consists of 3 classes. Sample just consists of a class, which obtained through cluster random sampling technique. Instrument used is problem solving ability test. Data is analyzed using descriptive statistics and inferential statistics. The study show that the problem solving based learning doesn't give good effect to problem solving ability, but it has average score is 67 or good level. Beside of that, the study also show that students have ability of understanding the problem with the average score is 75 or high level, ability of devising the plan with the average score is 66 or high level, ability of carrying out the plan with the average score is 50 or middle level, and the average score is 19 or very low level for ability of looking back.
\end{abstract}

Keywords: Problem Solving, Probability Theory

\section{INTRODUCTION}

Probability theory is one of compulsory subject that must be taken by students in Program Study of Mathematics IKIP PGRI Pontianak. In syllabus of probability theory, this subject consists of explanation about multiplication rule, permutation, combination, probability concept, probability calculation with multiplication, permutation, and combination rule, and distribution of random variables. Problem often presented by the subject are problem relating to daily problems, so it requires student to have problem solving ability. Newman said that a problem solving skill consists of convergent and divergent thinking for creating the solutions (Saphonhiranraka, 2015). And then, Polya (Widjayanti, 2011) said that there are 4 steps in problem solving, they are: (1)understanding the problem, (2)devising the plan, (3)carrying out the plan, dan (4)looking back. In Bransford (Pardjono, 2009) opinion, steps of problem solving consists of: (1) identify the problem, (2) define and represent the problem, (3) explore possible strategies, (4) act on the strategies, (5) look back and evaluate the effects of your activities. The researcher experience during teaching and learning about probability theory show that the students have difficulty in problem solving, especially in calculates the probability of an experiment. Because of that, researcher think it needs an effort to develop problem solving ability in probability calculation. One of the effort is giving teaching and learning using problem solving based learning. Galloti said that the technique of problem solving described here is called means-ends analysis. It involves comparing the goal with the starting point, thinking of possible ways of overcoming the difference (Pardjono, 2009). Pardjono mention that problem solving based learning can increase high-level cognitive ability, such as ability of analysis, synthesis, and evaluation (Pardjono, 2009). Referring to the study, researcher want to conduct a study to see the level of problem solving ability in each step of problem solving after being given problem solving based learning and to see the effect of problem solving based learning to the problem solving ability in probability calculation subject.

\section{METHOD}

Method of this study is experiment method with preexperimental design. Design of this study using one shotcase study. There are two variables: independent variable (problem solving based learning) and dependent variable (problem solving ability). The population of this study are students of fifth semester in Program Study of Mathematics 
IKIP PGRI Pontianak, consists of 3 classes. The sample is selected by cluster random sampling technique and obtained class A with total of 32 students. Steps of this study are: Step 1. Researcher give the treatment to the sample through problem solving based learning for 7 meetings in multiplication rule, permutation, combination, probability concept, and probability calculation subject. Step 2. After give the treatment, sample is given test for determine problem solving ability. Step 3 . The results of the test were scored by steps of problem solving according to Polya theory. Step 4 . The results of the tests were analyzed using descriptive statistic and inferential statistics. Descriptive statistics is used to description about problem solving ability according to steps of problem solving. Then, the date are grouped in 5 level, as shown in Table 1 below:

TABLE I

LEVEL OF PROBLEM SOLVING ABILITY

\begin{tabular}{cc}
\hline Score Interval & Level \\
\hline $81 \leq x \leq 100$ & Super High \\
$61 \leq x \leq 80$ & High \\
$41 \leq x \leq 60$ & Medium \\
$21 \leq x \leq 40$ & Low \\
$0 \leq x \leq 20$ & Super Low \\
\hline
\end{tabular}

(Budiyono, 2011)

Inferential statistics is used to answer the research hypothesis. The research hypothesis is problem solving based learning give good effect to problem solving ability. The effect of problem solving learning also were grouped in 5 level, as shown in Table II below:

\section{TABLE II \\ THE EFFECT OF PROBLEM SOLVING BASED LEARNING}

\begin{tabular}{cc}
\hline Score Interval & Level \\
\hline $81 \leq x \leq 100$ & Excellent \\
$61 \leq x \leq 80$ & Good \\
$41 \leq x \leq 60$ & Not good \\
$21 \leq x \leq 40$ & Bad \\
$0 \leq x \leq 20$ & Too bad \\
\hline
\end{tabular}

The hypothesis test using the test average in SPPS-18 application. One of the requirement of hypothesis testing is data must be normally distributed. Normality test is calculated using Kolmogorov-Smirnov test with significant degree $0,05(\alpha=0,05)$ Step 5. Researcher make a conclusion according to the result of descriptive and inferential statistics.

\section{RESULTS AND DISCUSSION}

\section{A. Results}

Problem solving based learning is done for 7 meetings: 1 th Meeting. The explanation of sets. 2nd Meeting. The explanation of multiplication rule. 3th Meeting. The explanation of permutation and combination. 4th Meeting. The explanation of probability concept and definition of probability. 5th Meeting. The explanation of probability calculation using multiplication rule. 6th Meeting. The explanation of probability calculation using permutation and combination. 7th Meeting. The explanation of conditional probability and independent probability. After complete for 7 meetings, then tests is given to the sample for determine problem solving ability. Tests using essay tests, consists of 6 questions. The questions will measure in each step of problem solving, that are (1) understanding the problem, (2) devising the plan, (3) carrying out the plan, and (4) looking back. The results of the tests were scored based on assessment rubric and analyzed. The first analysis to see level of problem solving ability based on the average score in each step of problem. The results of the first analysis shown in the Table III below:

$$
\text { TABLE III }
$$

The Results of Problem Solving Ability Test

\begin{tabular}{|c|c|c|c|c|}
\hline & Step 1 & Step2 & Step 3 & Step 4 \\
\hline $\begin{array}{l}\text { Number of } \\
\text { samples (n) }\end{array}$ & 32 & 32 & 32 & 32 \\
\hline 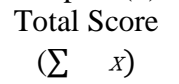 & 2395 & 2130 & 1570 & 600 \\
\hline Avarage $(\bar{X})$ & 75 & 66 & 50 & 19 \\
\hline
\end{tabular}

Next, the second analysis to see the results of hypothesis testing or to determine the effect of problem solving based learning to problem solving ability. The hypothesis test using the average test of one sample in SPPS-18 application. But before that, researcher do the normality test. The results of normality test shown in the Table IV below:

TABLE IV

THE RESUltS OF NORMALITY TEST

\begin{tabular}{|c|c|c|c|c|c|c|}
\hline & \multicolumn{3}{|c|}{ KolmogorovSmirnova } & \multicolumn{3}{|c|}{ Shapiro-Wilk } \\
\hline & Statistic & $\mathrm{df}$ & Sig. & Statistic & df & Sig. \\
\hline VAR00001 & .128 & 32 & $.200^{*}$ & .939 & 32 & .069 \\
\hline
\end{tabular}

Based on Table IV, value of sig is $0.2>0.05$. It means that data is normally distributed. The results of hypothesis test shown in the Table V below:

TABLE V

THE RESUlTS OF HYPOTHESIS TESTING

\begin{tabular}{ccccc}
\multicolumn{5}{c}{ THE RESULTS OF HYPOTHESIS TESTING } \\
& $\mathbf{4}$ & \multicolumn{3}{c}{ Test Value $=60$} \\
$\mathbf{d f}$ & $\begin{array}{c}\text { Sig. (2- } \\
\text { tailed) }\end{array}$ & $\begin{array}{c}\text { Mean } \\
\text { Difference }\end{array}$ \\
$\begin{array}{c}\text { University } \\
\text { Student's }\end{array}$ & -.777 & 31 & .443 & -4.031 \\
Score & & & & \\
\hline
\end{tabular}

Based on Table $\mathrm{V}$, value of sig is $0.443>0.05$. This shows that $\mathrm{H} 0$ is accepted. It means that the hypothesis of research is rejected. In other words, problem solving based learning doesn't give the good effect to problem solving ability. Although the hypothesis of research is rejected, but the average score of problem solving ability after being given problem solving based learning is 67 or good level.

\section{B. Discussion}

The first analysis show that there are differences in the level of problem solving ability for each step. In step of understanding the problem, the average score is 75 or high level. As well as first step, in step of devising the plan, the 
average score is 66 or high level. Different from the results shown in the completion of the second and third step, which is carrying out the plan and looking back, successively obtained an average score of 50 or medium level and 19 or super low level. It show that most of student have a good ability in understanding the problem, devising the problem, and carrying out the plan. This is caused by the use of problem solving based learning makes students familiar to solve the problem based on step of problem solving. In other words, a process of habituation becomes the most important factor for students in solving problems faced. The step of looking back, the students are encouraged to looking back the complete answer according to definition. In the fact, just a small percentage of student were able to answer the questions. It can be caused of the student less able to remember definition and theorem relating to probability calculation. The second analysis show that problem solving based learning doesn't give good effect to problem solving ability, but the average score of problem solving ability after being given problem solving based learning is 67 or good level. This result is considered reasonable, because learning is given for 7 meetings contains steps of learning suitable with steps of problem solving. So, during problem solving based learning takes place, students are constantly trained to solve problems by using the steps of problem solving. Same as Pardjono's statement, he said that problem solving based learning can increase the student's thinking ability (Pardjono, 2009). It is also stated by Wenno, that students science learning outcomes by using science module based problem solving better than conventional learning (Wenno, 2010).

\section{CONCLUSION}

The conclusion of this study are problem solving based learning doesn't give good effect to problem solving ability but it has an average score is 67 or good level and through this learning, the students have the ability of understanding the problem with the average score is 75 or high level and 66 or high score for the ability of devising the plan. But they just have the ability of act the plan with the average score is 50 or middle level and 19 or very low level for the ability of looking back. The other conclusion is lecturer should make an effort to improve understanding of the definition and theorem, particularly in probability theory. Beside of that, development of mathematical power must be accompanied by the process of practice to become a habit.

\section{REFERENCES}

Budiyono. (2011). Penilaian Hasil Belajar. Surakarta: UNS Press.

Budiyono. (2009). Statistik untuk Penelitian. Surakarta: UNS Press.

Pardjono dan Wardaya. (2009) Peningkatan Kemampuan Analisis, Sintesis, dan Evaluasi Melalui Pembelajaran Problem Solving. Jurnal Ilmiah Pendidikan. Cakrawala Pendidikan. November 2009, Th XXVIII No.3.

Saphonhiranraka, Samoekan, et al. (2005). Factors Affecting Creative Problem Solving in The Blended Learning Environment: a Review of a Literature. ProcediaSocial and Behaviour Sciences, 12 february 2015, volume 174, page: $2130-2136$

Sugiyono. (2014). Metode Penelitian Kombinasi. Bandung: Alfabeta.

Wenno, Izaak H. (2010). Pengembangan Model Modul IPA berbasis Problem Solving Method Berdasarkan Karakteristik Siswa dalam Pembelajaran Di SMP/Mts. Jurnal Ilmiah Pendidikan. Cakrawala Pendidikan. November 2010, Th XXIX. No.2.

Widjayanti, Djamilah Bondan dan Wahyudin. (2011). Mengembangkan Kemampuan Pemecahan Masalah dan Belief Calon Guru Matematika Melalui Strategi Perkuliahan Kolaboratif. Jurnal Ilmiah Pendidikan. Cakrawala Pendidikan. November 2011, Th XXX No. 3. 